\title{
A Roadmap for Malaysia Logistician Competency: A Discussion from Literature Review
}

\author{
Dazmin Daud (Corresponding author) \\ Chartered Institute of Logistics and Transport Malaysia \\ Email: daazmin@yahoo.com \\ Mok Wei Yee \\ Inventory Planner, Esthetics International Group Malaysia
}

Siti Norida Wahab

Faculty of Business and Information Science, UCSI University, Malaysia

Accepted: Sep 16, 2013 Published: Oct 27, 2013

Doi:10.5296/ijhrs.v3i4.4469 URL: http://dx.doi.org/10.5296/ijhrs.v3i4.4469

\begin{abstract}
The purpose of this conceptual paper is to explore the literature pertaining to logistician competency. It discusses stakeholders in logistics industry to pursue further research on tapping current elements in competency for future logisticians. The discussion includes the general view about logistician competency, the relationship between logistics and competency, and the Malaysia logistics industry in general. The paper wish to present a proposition where knowledge, skills, internship, and curriculum will attribute to Malaysia logistician competency.
\end{abstract}

Keywords: Malaysia, competency, knowledge, skills, internship, curriculum

\section{Introduction}

The purpose of this conceptual paper is to explore the literature pertaining to logistician competency. It triggers stakeholders in logistics industry such as logistics professionals, educators, trainers, human resource development managers, and the Government to pursue further research on tapping current elements in competency for future logisticians. This paper has two specific objectives: first, it will encourage managers in logistics firms to identify important skills and knowledge for logisticians; and second, it will encourage academicians to design logistics syllabus after matching with the current and future logistics educational needs for logistics graduates. 
As the logistics industry develops globally, there is a concern for preparing competent logisticians to ensure this industry continuously contributes to nation's economy (Thai, Cahoon \& Tran, 2011). This is because logistics plays a crucial role in assisting economic growth for any countries. For example, in Malaysia, the logistics industry is expected to grow at the annual growth rate of 11.6 percent to reach RM203.71 billion in 2016 (see Figure 1). To gain competitive advantage, it is a must for logistics companies to have well-trained, knowledgeable and skilled logisticians. Murphy and Poist (2007) have pointed out that logisticians must be multi-talented with knowledge and skills while Afiouni (2007) has stressed the relationship between competent workers and competitive advantage.

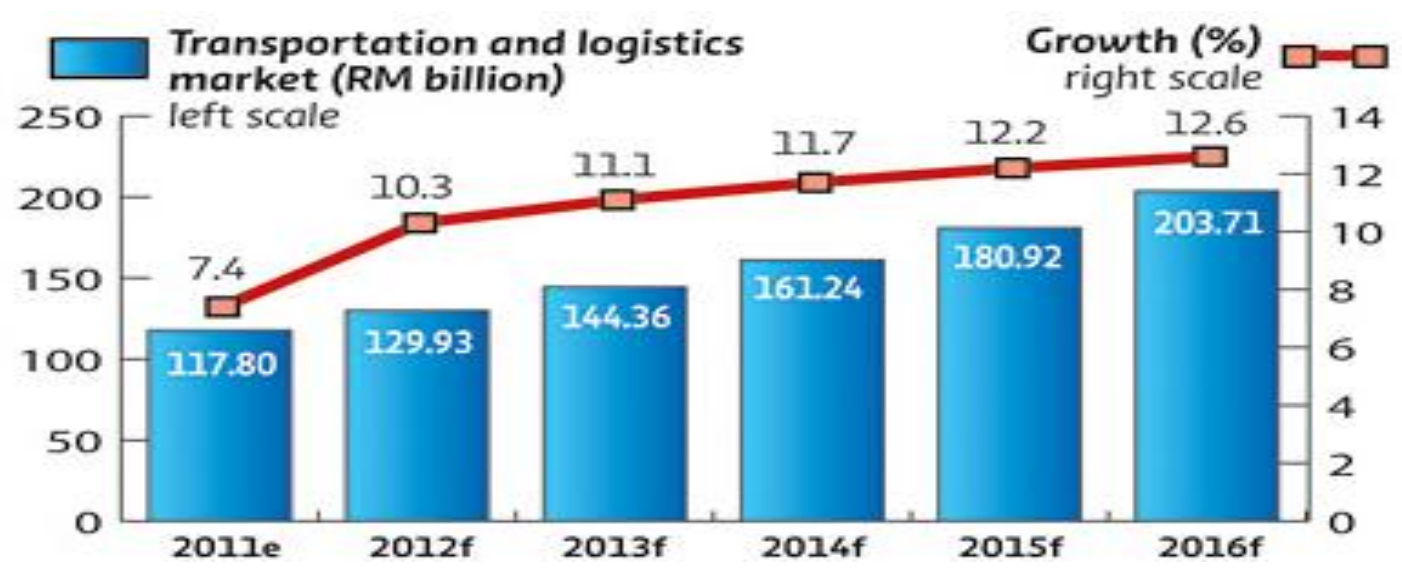

$\mathrm{e}=$ estimate $\mathrm{f}=$ forecast

Figure 1: Market projection for Malaysian transportation and logistics market (Source: Business Times, 2012).

\section{General View about Logistician Competency}

Evidence from $\mathrm{Wu}$ (2007) indicates that competency plays an important role in ensuring productivity in logistics activities. Education institutions that provide logistics programs must able to produce syllabi which is able to produce marketable logistics graduates (Richey, Tokman \& Wheeler, 2006). In the case of logistics companies, crucial key areas for logistician competency are referred to the Business, Logistics and Management (BLM) Model (Murphy \& Poist, 2007). According to the guidelines from the academic and industry perspectives, logistics graduates as well as logistics practitioners would able to transform themselves into competent logisticians. It will be a waste of effort if academicians and practitioners are not able to reconcile their interest and needs for the development of logistician competency (Gravier \& Farris, 2008). 
In order to reduce the variance between academic and industry, the practice of logistics internship program (LIP) by the logistics students into logistics companies is considered to be an appropriate solution. LIP provides opportunities for logistics students to gain experience in actual logistics operation. This will get them exposed to the real-life working environment at the workplace. The students may able to relate what they have learned in class into real logistics operation. In addition to that, internship not only enhances students' soft skills such as self-confidence, social skills, practical knowledge but also job opportunity (Lim, Dazmin \& Jonathan, 2012).

\section{Relationship between Logistics and Competency}

With the growing acceptance of logistics as critical business concern, it is imperative to develop appropriate management skills and competencies for logisticians. Knowledge and skills are perceived as important factors for logistics firms to stay competitive in the $21 \mathrm{st}$ century (Chapman, Soosay \& Kandampully, 2002). New trends of knowledge and skills such as supplier relationship management and market knowledge is perceived as necessary for logisticians in conjunction with globalization (Crook et al., 2008).

Logistics companies are seeking to fill in logistics positions with a mix of seasoned professionals and entry-level graduates with degrees in logistics (Myers et al., 2004). Meanwhile, $\mathrm{Wu}$ (2007) has highlighted that this industry is lacking insufficient human resources in logistics expertise. The challenge is that competent logistics managers must be able to have two distinctive competencies namely formal and informal competencies (Thai et al., 2012). Formal responsibilities refer to traditional functional responsibilities that require logistics skills and knowledge such a warehousing and inventory management. Informal responsibilities include planning, financial budgeting and training and motivating skills.

In their study, Thai et al. (2011) have demonstrated that appropriate skills and knowledge would contribute to competent logisticians. This can be materialized when industry and academicians work together in order to produce future competent needs for logisticians. A combination of theory and practical in logistics will enable the logisticians to become an effective manager (Murphy \& Poist, 2007).

Tage Skjoet-Larsen (2000) has performed a pilot study on current and future competencies needed by logisticians in Western Europe. The findings indicated that respondents still perceived certain logistics skills as important to logisticians. These skills are materials handling, warehousing, distribution and purchasing. From the perspective of Asia, a combination of hard and soft skills such as logistics operation, managerial skills, technological skills, and business management skills were perceived as vital in logistics operation (Wu, 2007).

Other literature emphasized the importance of soft skills in logistics. For instance, there are 
seven soft skills perceived as important to logisticians (Keller \& Ozment, 2009). These skills are teamwork, written communication, oral communication, prioritizing, seeing the "big" picture, problem solving and decision making. As for the top managers in logistics companies, understanding logistics strategy is a must (Green, Whitte \& Inman, 2008). Their argument was that a good strategy would lead towards a positive financial performance towards a positive financial performance output. In a situation where the logisticians involve in procurement, purchasing skill is vital for the success (Andersson \& Norman, 2002). In order to ensure this happens, logisticians must pose effective decision-making, negotiation, and process management skills and knowledge.

Within the scope of logistics educational needs, Wu (2007) has studied the role of logistics curriculum on employability among logistics graduates. Their findings showed that there is a need for logistics courses offered by higher education institutions to be blended with the concepts and techniques of the non logistics courses such as management and business. This will be able to make logistics graduates more marketable in the logistics industry.

\section{Malaysia Logistics Industry}

The Malaysia's Third Industrial Master Plan (IMP3) 2006-2020, which launched in $18^{\text {th }}$ August 2006, categorizes Malaysia logistics industry into two types of service providers, namely transport service providers and logistics service providers. The transport service providers include transport operators of air, sea, road and rail, multimodal and terminal operators. The logistics service providers, on the other hand, consist of facilitation services (freight forwarders, custom brokers, ship brokers, shipping agents, consolidators, and non-vessel operating common carriers), distribution services (warehousing and transportation, inventory management, and domestic and regional distribution and courier companies), and integrated logistics services (third party logistics providers and lead logistics providers), and other business support services.

In relation to logistician competency, the Malaysian government is aware at focusing this issue. A comprehensive strategy has been developed in the IMP3 in order to prepare competent logisticians (Third Industrial Master Plan 2006-2020, 2006). These include:

1. Positioning the services sector as a major source of growth by:

- strengthening the efficiency and competitiveness of the sector;

- enhancing the development and promotion of services sectors;

- developing regional centers for education, distribution, health and tourism services;

- creating greater links with manufacturing; and

○ undertaking progressive liberalization.

2. Developing innovative and creative human capital by:

- matching the supply of talents and expertise with market requirements; 
○ increasing the supply of technically skilled, knowledgeable and ICT-trained workforce;

- encouraging collaboration between training institutes and industry to optimize the utilization of resources and facilities; and

\section{Future Roadmap and Conclusions}

From the above discussion, a conceptual framework can be developed (see Figure 2). The proposition for this framework is that knowledge, skills, internship, and curriculum have a relationship with Malaysia logistician competency.

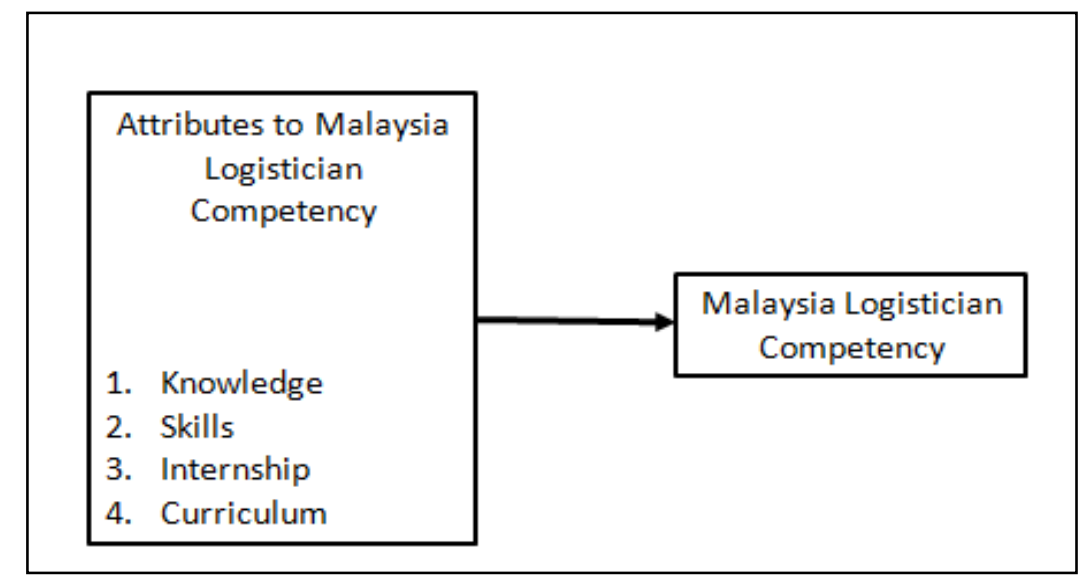

Figure 2: A Conceptual Framework for Malaysia Logistician Competency

Emphasizing this area will benefit both logistics industry and academicians. In the case of logistics industry itself, employers will be able to identify areas of competency which are critical for logisticians. The above conceptual framework will assist employers to design appropriate training and development programs for obtaining required competency level.

As for the academicians, this study will assist them in designing employable curriculum for logistics program. It will have learning outcomes that would provide appropriate knowledge and skills to prepare logistics graduates to be accepted by employers in the logistics industry.

In conclusion, both academia and industry must coordinate their expertise together in order to produce future logisticians with excellence in theory as well as practical skill set.

\section{Reference}

Afiouni, F. (2007). Human resource management and knowledge management: A road map toward improving organizational performance. Journal of American Academy of Business, 11(2), 124-130. 
Andersson, D. \& Norman, A. (2002). Procurement of logistics services - a minutes work or a multi-year project? European Journal of Purchasing \& Supply Management, 8(1), 3-14. DOI: http://dx.doi.org/10.1016/S0969-7012(01)00018-1

Business Times (2012). Logistics industry set to grow $10.3 \mathrm{pc}$ to RM129.9b, July, $1^{\text {st }} 2012$.

Chapman, R.L., Soosay, C. \& Kandampully, J. (2002). Innovation in logistics services and the new model: A conceptual framework. Managing Service Quality, 12(6), 358-371. DOI: $10.1108 / 09604520210451849$

Crook, T.R., Giunipero, L., Reus, T.H., Handfield, R. \& Williams, S.K. (2008). Antecedents and outcomes of supply chain effectiveness: An exploratory investigation. Journal of Managerial Issues, 20(2), 161-177.

Gravier, M.J. \& Farris, M.T. (2008). An analysis of logistics pedagogical literature: Past and future trends in curriculum, content, and pedagogy. International Journal of Logistics Management, 19(2), 233-253. DOI: 10.1108/09574090810895979

Green, K.W. Jr., Whitte, D. \& Inman, R.A. (2008). The impact of logistics performance on organizational performance in a supply chain context. Supply Chain Management: An International Journal, 13(4), 317-327. DOI: 10.1108/13598540810882206

Keller, S.B. \& Ozment, J. (2009). Research on personnel issues published in leading logistics journals: What we know and don't know. The International Journal of Logistics Management, 20(3), 378-407. DOI: 10.1108/09574090911002832

Lim, Y.P., Dazmin, D. \& Jonathan, K.R. (2012). Perceptions of Logistics Students on Internship Programme: The Case of Private Higher Institution in Malaysia. Canadian Social Science, 8(4), 1-7. DOI: 10.3968/j.css.1923669720120804.1123

Murphy, P.R. \& Poist, R.F. (2007). Skill requirements of senior-level logisticians: A longitudinal assessment. Supply Chain Management: An International Journal, 12(6), 423-431. DOI: 10.1108/13598540710826353 
Myers, M.B., Griffith, D.A., Daugherty, P.J. \& Lusch, R.F. (2004). Maximizing the human capital equation in logistics: Education, experience, and skills. Journal of Business Logistics, 25(1), 211-232. DOI: 10.1002/j.2158-1592.2004.tb00175.x

Richey, R.G., Tokman, M. \& Wheeler, A.R. (2006). A supply chain manager selection methodology: Empirical test and suggested application. Journal of Business Logistics, 27(2), 163-190.

Tage Skjoett-Larsen, (2000). European logistics beyond 2000. International Journal of Physical Distribution \& Logistics Management, 30(5), 377 - 387. DOI: $10.1108 / 09600030010336144$

Thai, V., Ibrahim, K.B., Ramani, V. \& Huang, H.Y. (2012). Competency profile of managers in the Singapore logistics industry. The Asian Journal of Shipping and Logistics, 28(2), 161-182. DOI: http://dx.doi.org/10.1016/j.ajs1.2012.08.002

Thai, V.V., Cahoon, S. \& Tran, H.T. (2011). Skill requirements for logistics professionals: Findings and implications. Asia Pacific Journal of Marketing and Logistics, 23(4), 553-574. DOI: $10.1108 / 13555851111165084$

Third Industrial Master Plan (2006). The Ministry of International Trade and Industry. Malaysia.

Wu, Y.J. (2007). Contemporary logistics education: An international perspective. International Journal of Physical Distribution \& Logistics Management, 37(7), 504-528. DOI: 10.1108/09600030710776455 